\title{
Ecological Scenarios and Parasite Diversity in Anurans of West Africa: A Review
}

\author{
Martins S. O. Aisien *, Omoyemwen Edo-Taiwo and Abigail A. Imasuen
}

Citation: Aisien, M.S.O.; Edo-Taiwo,

O.; Imasuen, A.A. Ecological

Scenarios and Parasite Diversity in Anurans of West Africa: A Review. Diversity 2021, 13, 223. https:// doi.org/10.3390/d13060223

Academic Editors: Michael Wink, Ulrich Sinsch and Patrick Leander Scheid

Received: 6 April 2021

Accepted: 15 May 2021

Published: 21 May 2021

Publisher's Note: MDPI stays neutral with regard to jurisdictional claims in published maps and institutional affiliations.

Copyright: (c) 2021 by the authors Licensee MDPI, Basel, Switzerland. This article is an open access article distributed under the terms and conditions of the Creative Commons Attribution (CC BY) license (https:// creativecommons.org/licenses/by/ $4.0 /)$
Laboratory of Parasitology Research, Department of Animal and Environmental Biology, Faculty of Life Sciences, University of Benin, Benin City P.M.B. 1154, Nigeria; omoyemwen.edo-taiwo@uniben.edu (O.E.-T.); abigail.imasuen@uniben.edu (A.A.I.)

* Correspondence: aisien@uniben.edu

\begin{abstract}
This paper is a survey of the parasite diversity, prevalence and infection intensity in anurans in diverse ecological settings in West Africa. The settings included natural habitats (rainforests, freshwater creeks, Guinea and Sudan savannas), monoculture plantations (cocoa, cotton and oil palm), urbanized and urbanizing rainforest biotopes and polluted environments due to oil industry activities. The natural habitats had higher amphibian species diversity, moderate parasite prevalence and low infection intensity, showing a balance in the host/parasite relationship. These habitats yielded most of the monogeneans, among which were new species. The freshwater creek biotope had low amphibian diversity, but hosts from this environment harbored several parasite taxa, a situation attributed to a prolonged wet season, high environmental humidity and persistent breeding pools for insect vectors in this area. The monoculture plantations were characterized by high parasite prevalence but lower infection intensity. For example, in the Pendjari Biosphere Reserve in Bénin Republic, the Agricultural Zone (AZ) had higher parasite prevalence values, while the National Park (NP) and Buffer Zone (BZ) had higher infection intensities. Higher prevalence was attributed to the single or combined effects of vector population explosion, immune-suppression by agrochemicals, nutrient enrichment and eutrophication from fertilizer use. The lower infection intensity was attributed to the inhibitory effect of the pesticide-contaminated environment on the free-living larval stages of parasites. The adverse effect of pesticide contamination was also evident in the lower infection intensity recorded in the anurans from the cocoa plantations at Ugboke in comparison to those from the pesticide-free village settlement. Urbanization reduced host diversity and numbers and increased the vector population, resulting in unusually high parasite prevalence and infection intensities at Diobu and Port Harcourt and high prevalence recorded for Ophidascaris larvae in the anurans of Evbuabogun. Oil pollution in the mangrove community reduced both host and parasite diversity; infection intensity was also low due to the adverse conditions confronting free-living stages of parasites in their development milieu. The high prevalence values obtained for monogeneans (Polystoma spp.) in Ptychadena spp. from Ogoniland was presumed to have resulted from host tadpole sequestration and exposure to high oncomiracidia burden in the few hospitable ponds. Also reviewed is the phenomenon of amphibian paratenism, a strategy on which many helminth parasites rely on for their trophic transmission to their definitive hosts.
\end{abstract}

Keywords: ecology; parasite prevalence; infection intensity; host specificity; amphibian paratenism

\section{Introduction}

The West African sub-region is located within the geographical coordinates of $4^{\circ} \mathrm{N}-20^{\circ} \mathrm{N}$; $15^{\circ} \mathrm{E}-18^{\circ} \mathrm{W}$. It is bounded to the north by the Sahara Desert, to the East by Cameroon and to the west and south by the Atlantic Ocean (Figure 1). The region is made up of 16 countries of which five (Gambia, Ghana, Liberia, Sierra Leone and Nigeria) are English speaking, nine (Burkina Faso, Bénin, Côte d'Ivoire, Guinea, Mali, Mauritania, Niger, Senegal and Togo) are Francophone and two (Guinea Bissau and Cape Verde) are Portuguese. 


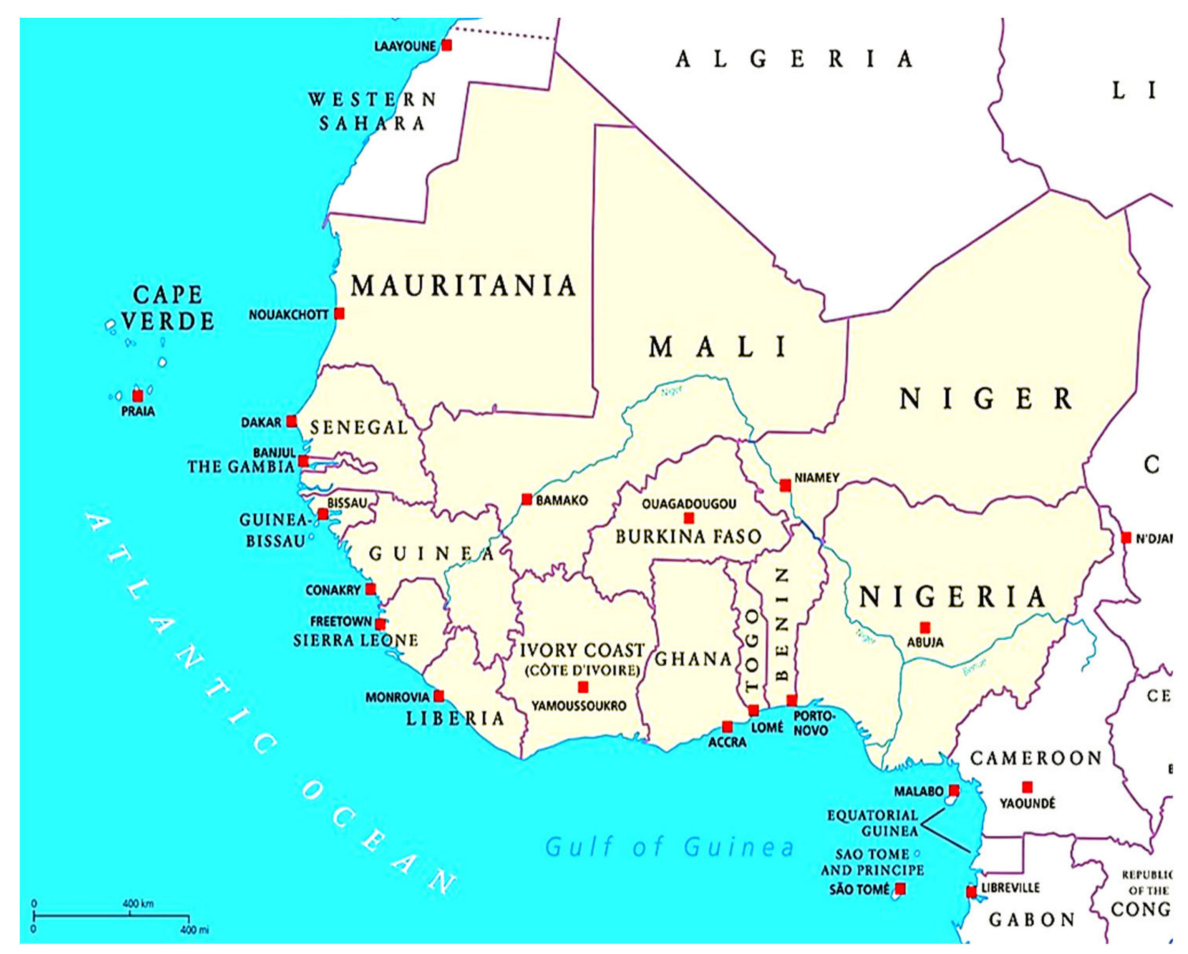

Figure 1. Map of countries in the West African sub-region.

The region is divided into different bioclimatic zones ranging from the brackish mangrove biotope, to forest swamps, tropical rainforest, the derived savanna and the Guinea savanna. The northern part of Bénin is located in the Sudan savanna. Anthropogenic activities, mainly in the form of agricultural land use and urbanization, have altered the pristine order in these biotopes, leading to massive loss of natural vegetation, habitat fragmentation and loss of amphibian species. Oil industry activities in the Niger Delta of Nigeria and its attendant pollution from oil spills and refinery effluents have resulted in severe environmental degradation, which has impacted negatively on the amphibian fauna diversity of the region.

Studies on the parasites of amphibians in West Africa date back to the 1920s, with more investigations undertaken in Francophone countries (Bénin, Cameroon, Central African Republic, Gabon, Ivory Coast, Togo) [1-16]. These studies were purely descriptive, with emphasis on the flatworms (monogeneans and digeneans) parasitizing anurans in these countries. The paper by Durette-Desset and Batcharov [8] was an exception in that it described two nematodes (Gendria leberrei and Camallanus dimitrovi) recovered from amphibians in Togo. A more recent paper by Daniel et al. [16] reported on the gastro-intestinal parasites of Conraua goliath in the littoral region of Cameroon, which recorded eight nematodes, two digeneans and a pentastomid. Far fewer studies were undertaken in Anglophone West Africa [17,18]. Rees [17] described two trematodes of the genus Haematoloechus (H. exoterorchis and H. micrurus) from Rana (Hoplobatrachus) occipitalis, while Fischthal and Thomas [18] undertook further investigations into the trematodes of amphibians in Ghana. Later studies by Jackson and Tinsley dealing with host specimens from West Africa and elsewhere in Africa [19-22] focused on the taxonomy, evolutionary relationships, host range, geographical distribution and host specificity of some helminth parasites [19-21]. A later study investigated the role of hymenochirine anurans in camallanid nematode life cycles [22]. Our initial studies of amphibian parasites were also descriptive [23-26].

A new perspective connecting amphibian parasitism with host ecology came into focus from the contributions of environmental parasitologists [27-37]. Information from these studies assisted us in finding a nexus between host environments and parasite diversity, distribution and host specificity. 
The approach adopted in this review is to examine the infection patterns in anurans from natural habitats and use them as backgrounds against which deviations observed in hosts from environments impacted by human activities are evaluated. In this review, we examined the parasite diversity in amphibians from various ecological settings where amphibians and their parasites have been studied in West Africa. The ecological scenarios considered include (1) natural habitats (rainforests, savannas, fresh water swamps), (2) monoculture plantations (cocoa, cotton and oil palm), (3) oil polluted environments and (4) urbanizing and urbanized habitats.

Most of the current investigations into parasite diversity in anurans from West Africa are being undertaken in Nigeria. This may inadvertently skew the examples cited in this discussion to literature emanating from this area.

\section{Natural Habitats}

\subsection{Rainforest Biotopes}

The tropical rainforests are located between $23.5^{\circ} \mathrm{N}$ and $23.5^{\circ} \mathrm{S}$ of the equator. The vegetation consists of high canopy trees and thick undergrowth, with high levels of precipitation and atmospheric humidity, which is why it supports a high diversity of amphibians [38]. Quite a number of investigations on the parasitofauna of anurans have been conducted in the rainforest biotope in Nigeria, the first of which was in Benin City, Nigeria [23]. On account of the altered nature of the study sites, very few anuran species were encountered; most of these were disturbance-tolerant species, which surprisingly harbored 26 endoparasites, excluding monogeneans. Insights into the parasitic infections of anurans from natural forest biotopes came from the investigations at the Gelegele Forest Reserve (GFR) [26], followed by studies at the Okomu National Park (ONP) [39].

Among the anurans encountered at the Gelegele Forest Reserve by Aisien et al. [26] were forest specialists, including Chiromantis rufescens, Ptychadena longirostris and Hyperolius fusciventris. Overall parasite prevalence among the 11 anurans investigated was quite low (0.6-10.8\%), but when prevalence in the dominant species (Aubria subsigillata and Ptychadena spp.) were separately analyzed, the prevalence recorded for A. subsigillata for the eight parasites encountered ranged from $9.1 \%$ to $45.5 \%$, while that recorded for Ptychadena spp. was between $2.63 \%$ and $51.72 \%$. The infection pattern reflected a stable environment, devoid of anthropogenic activities disrupting the equilibrium in host-parasite interactions. Three monogeneans (Metapolystoma cachani and two other Polystoma spp.) were recorded along with four digeneans (Haematoloechus aubriae, Halipegus sp., Pleurogenoides tener and Mesocoelium monas), which were new records for Nigeria.

The ONP yielded a higher anuran species diversity (40 species), dominated by the families Hyperoliidae and Ptychadenidae [39]. Twenty-eight parasite species, comprising ten monogeneans, six digeneans, eleven nematodes and an acanthocephalan cystacanth, were recorded. The finding of ten monogeneans in this protected sanctuary further buttressed the fact that their absence in the anurans from Benin City and its environs was due to the altered nature of the collection sites. A new Polystoma species, Polystoma okomuensis, was described from Phlyctimantis boulengeri [40], and a second species recorded in Hyperolius sylvaticus awaits description. The other Polystoma spp. recovered were Polystoma aeschlimanni, P. baeri, P. chiromantis, P. dorsalis, P. ebriensis, P. grassei and P. pricei, which have records elsewhere in Africa [6,41-47]. Also recovered was Metapolystoma cachani, which was earlier recorded at GFR [26] and much earlier recorded in Togo and Côte d'Ivoire [47,48]. New geographical records among the digeneans included Ostioloides rapiae and Halipegus sp. A unique phenomenon in which larvae of an unidentified nematode co-encysted with proteocephalid cestode larvae was recorded in Silurana tropicalis [49]. As observed at GFR, parasite prevalence and infection intensity were generally low, except in a few cases where the number of host species examined were few, giving an apparent high prevalence. 


\subsection{Freshwater Creeks}

The freshwater creek community of Ase in Delta State, Niger Delta of Nigeria was unique in a number of respects. Although only 125 anuran specimens (two Sclerophrys maculata, one S. regularis, six Hymenochirus sp., 44 Amnirana galamensis, 5 Hoplobatrachus occipitalis, 23 Ptychadena bibroni, 11 P. mascareniensis, 10 P. oxyrhynchus and 5 P. pumilio) were examined, 32 endoparasites were recovered. These included pentastomids, cestodes, monogeneans, digeneans and nematodes. Sclerophrys regularis, which is terrestrial, harbored the lowest number (2) of parasites, while the highest number (11) was recovered from P. bibroni. While most of the parasites recovered were adults, some larval stages that use anurans either as intermediate or paratenic hosts were also encountered. Polystoma galamensis, a monogenean commonly associated with host species Amnirana galamensis from the savannah biotope [24,25], was recorded in this location, albeit with low prevalence and infection intensity [50]. Although Amnirana galamensis was considered an accidental host for the larval brachylaimid recovered in this frog, this infection led to the unraveling of the intermediate and definitive hosts of this trematode in the creek environment (M.S.O. Aisien, unpublished data). The major factors that may have influenced the high parasite diversity in this habitat were the long duration of the wet season and the consequent high environmental humidity in this creek community. This was very conducive for soiltransmitted helminth parasites. These environmental factors also ensured the continuous availability of stagnant water bodies, where mosquitoes bred in large numbers. We suspect these mosquitoes are the vectors of the Foleyellides and Oswaldocruzia spp. recorded in the frogs from this habitat.

\subsection{The Savannas}

The savanna is a region of lower precipitation when compared to the rainforest biotopes further south. The vegetation is grassland, in addition to deciduous trees; there are six months of rainfall (May to October) and six months of dry season (November to April) [51]. These conditions place a limitation on the amphibian fauna composition of this zone. Aisien et al. [25] recorded four anurans (Bufo regularis, B. maculatus, Dicroglossus occipitalis and Amniana galamensis) at New Bussa, while Anele et al. [51] recorded nine savanna species (Sclerophrys regularis, Kassina senegalensis, Afrixalus vittiger, Silurara tropicalis, Xenopus fischbergi, Pyxicephalus cf. edulis, Hoplobatrachus occipitalis, Amnirana galamensis and Ptychadena pumilio) in Zaria. In this ecological scenario, where rainfall is for a short duration and the area is devoid of forest cover to reduce evaporative water loss, the opportunity for parasite transmission is restricted to a few available water bodies, and reproductive success is restricted to parasites that are adequately adapted for survival and propagation. An excellent example of such adaptation is found in Eupolystoma alluaudi, whose oncomiracidia in an internal cycle of re-infection, hatch out in the host urine and establish themselves directly on the bladder wall along with their parents [52]. This way, the parasite is able to avoid the risk of reproduction in an unpredictable external environment. Besides E. alluaudi, other helminth parasites were also recorded (11 in New Bussa and 6 in Zaria). At the Pendjari Biosphere Reserve, located in the Sudan savanna of Bénin, [53] recorded 14 anuran species from eight families, which played host to 18 helminth parasites. In all, there seems to be some uniformity in the dominant parasite species in this biotope: nematodes and trematodes predominate in the three study locations. The monogenean Polystoma galamensis was specific to Amnirana galamensis, Eupolystoma alluaudi to bufonids, while Haematoloechus spp. and Camallanus dimitrovi were similarly host specific, occurring only in Hoplobatrachus occipitalis. The report of Camallanus macrocephalus in two pipid anurans (Xenopus fischbergi and Silurana tropicalis) by Anele et al. [51] showed that this nematode is not host specific but has a wide distribution among pipid anurans, as it was first described by Jackson and Tinsley [19] from X. borealis in Kenya. 


\section{Altered Environments}

\section{Monoculture Plantations}

Agriculture is one of the major land use forms in Africa, ranging from small holdings by individuals or families to monoculture plantations owned by multi-nationals. Plantation types include those of oil palm, cocoa, rubber and cotton. Associated with some of these plantations (cotton and cocoa) is pesticide use to mitigate crop damage and herbicides for weed control. Pesticides have an immunosuppressive effect on anurans when they are exposed at some critical stages in their development, rendering them more susceptible to trematode infections $[35,36]$ and the risk of limb deformities $[28,36]$. Pesticide-contaminated environments also inhibit the development and transmission of the free-living stages of helminth parasites [29], resulting in high prevalence and low infection intensity. While records of limb deformities due to pesticide use have not been reported in West Africa, their effects on parasite prevalence and infection intensity in anurans are evident. In the Pendjari Biosphere Reserve, Bénin, where Endosulfan and DDT were applied to control cotton pests in the Agricultural Zone (AZ), their effect on the pattern of helminth parasitic infections in anurans was unequivocal when compared with results from the National Park (NP) and the Buffer Zone (BZ) [53]. For example, the prevalence of acanthocephalan cystacanths was higher in Phrynobatrachus latifrons caught in the AZ, while those from the BZ had higher infection intensity. It was postulated that changes in the landscape of the $\mathrm{AZ}$ promoted higher vector population and infection, leading to higher parasite prevalence $[33,34]$. An alternative argument was that the immunosuppressive effect of pesticides on the host ( $P$. latifrons) may be responsible for the higher prevalence observed in the AZ [35]. The lower infection intensity also recorded in the frogs from the AZ was attributed to the inhibitory effect of the pesticide-contaminated environment on the development and transmission of the larval stages of these parasites [29]. Further influence of pesticide use in Pendjari was observed in the pattern of trematode infection in the frogs examined. It was observed that infection with digeneans occurred predominantly in hosts collected from the AZ. This was linked to a pesticide-induced increase in algal density, which resulted in increased snail density and increased cercarial output, manifesting in increased trematode infection in this zone. A similar trend was observed by Rohr et al. [36], where the herbicide atrazine augmented the richness and abundance of snail intermediate hosts of trematodes, thus increasing the abundance of cercariae infecting the frog Lithobates pipiens. The preponderance of trematode infections in the AZ was also linked to the immunosuppressive effects of pesticides [36], which made them more susceptible to trematode infections. Nutrient enrichment from fertilizer use and the resultant eutrophication were also thought to have led to increased algal density in the AZ, driving greater snail abundance and more infection in intermediate hosts [53]. Pesticide influence on parasites was not restricted to trematodes; it was also observed with nematodes [30]. For example, the prevalence of Rhabdias sp. in Phrynobatrachus latifrons in the BZ was approximately 14 times higher when compared with those from the $\mathrm{AZ}$, leading to the conclusion that the pesticide-free environment in the BZ was more conducive for the development and transmission of the soil-dwelling stages of these lungworms. It would appear that Rhabdias bufonis in S. maculata fared better in the $\mathrm{AZ}$, as infection with this nematode was only recorded in the AZ. Since the life cycle of this species is no different from those of other Rhabdias spp., it was concluded that these toads may have been collected near human habitations or near streams in the AZ, where direct pesticide application was rare or absent. Similarly, prevalence and infection intensity of Amplicaecum sp. in S. maculata was also higher in the NP, where the inhibitory effect of pesticides was absent.

Cocoa plantations represent another habitat where the effect of pesticide use has been evaluated [54]. Although cocoa plantations alter the pre-existing natural habitat, these plantations provide the anurans therein with a variety of microhabitats [55,56]. Pesticides applied in the Ojo-Camp cocoa plantations for pest control included Gamalin, Avesthrin (Cypermethrin 10\% EC), Scorpion, Best, Instakill and Ridonul Gold 66WP, while the herbicide Weed Crusher was used for weed control. An investigation of the helminth parasitic 
infections of leaf litter frogs (Arthroleptis and Phrynobatrachus spp.) and ground-dwelling anurans potently demonstrated the effects of pesticide and herbicide use on the pattern of helminth parasitic infections in these amphibians $[57,58]$. Despite the pesticide contamination of the leaf litter, high species richness and diversity of parasites (15 parasites) were recorded among the leaf-litter frogs [57]. The parasites recovered included cestodes (Cylindrotaenia jaegerskioeldi, Ophiotaenia sp. and larvae of two Proteocephalus spp.), digenetic trematodes (two Mesocoelium spp. and a strigeoid larva) and eight nematode species ( $\mathrm{Am}$ plicaecum sp., Aplectana sp., Cosmocerca ornata, Cosmocerca sp., Foleyellides sp., Physaloptera sp., Rhabdias sp. and Ascaridida sp. larva), albeit with low infection intensity, ranging from 1 to 12 parasites/infected hosts. The low infection intensity was a consequence of the inhibitory effect of pesticides/herbicides on the survival of the free-living stages of these parasites [29]. Furthermore, the use of these agrochemicals may also have eliminated vectors transmitting some of the parasites. The effects of these agrochemicals become more apparent when results obtained from the ground-dwelling anurans Aubria subsigillata, Amnirana spp. (A. albolabris and A. galamensis), Sclerophrys spp. (S. maculata and S. regularis), Ptychadena spp. (P. equiplicata, P. longirostris, P. mascareniensis, P. oxyrhynchus and P. pumilio) and the semi-aquatic Hoplobatrachus occipitalis collected from both the village settlement (free of agrochemical application) and the cocoa plantations (with pesticide/herbicide contamination) are compared. A careful look at some anuran families and their infection pattern was quite insightful. For example, among the Bufonidae (S. maculata and S. regularis), more parasite species were recorded in the specimens collected from the village settlement (VS). Prevalence was generally low in both the VS and in the cocoa plantations. Infection intensity was higher, however, in the toads from the VS, which is indicative of a more conducive environment for parasite development and transmission.

Of the two frog species (Aubria subsigillata and Hoplobatrachus occipitalis) that occurred only in the cocoa plantation, A. subsigilatta was the more susceptible, harboring 16 parasites, while H. occipitalis was infected with only four parasites (Table 1 ). The parasite burden recorded in H. occipitalis in this study is in sharp contrast to the report in the savannahmosaic zone of Edo State, Nigeria [24], where this frog harbored as many as 13 helminth species. This finding is similar to the report on specimens of this frog from the mangrove of the Niger Delta of Nigeria, where the holding ponds had acidic $\mathrm{pH}$ values ranging from 5.3-6.1 [58].

The contrasting parasite burdens may also highlight the fact that the degree of immune suppression may vary among frogs. Infections recorded among the Ptychadenidae were mostly among the immune-suppressed specimens from the cocoa plantation; the low parasite burden in these grass frogs pointed to the inhibitory effect of agrochemicals in the developmental milieu of the parasites.

Monoculture plantations like the oil palm may inadvertently increase the range of some parasitic infections. In the study of the amphibian diversity and helminth parasitic infections of anurans at the Okomu Oil Plantations, Ovwah [59] reported a number of cestodes but did not encounter the larval forms of the cestode Diplopylidium. In another study by Agbosua [60] at the Extension II of the same plantation, cysticercoids belonging to this genus were recovered from Sclerophrys maculata, Phrynobatrachus calcaratus and Ptychadena mascareniensis (prevalence: $8.3 \%, 27.3 \%$ and 10\%, respectively). Bush cats domicile in the High Conservation Value Areas (HCVAs) and adjoining bushes forage at night for ripe oil palm fruits in the plantations, and their fecal droppings, containing the eggs of this cestode, are consumed by arthropod hosts, which pass the infection to the anuran paratenic hosts. Adults of this parasite have been recovered from Civet cats [61] (see details in the section on Amphibian paratenism). Another interesting observation made at the Extension II plantation was that all anurans harboring the trematode Mesocoelium were, without exception, infected with a single Mesocoelium species (Mesocoelium monodi), creating what may be referred to as "infection homogeneity" with respect to this parasite among the anurans in the plantation. This scenario must have arisen by the consumption 
of a common arthropod intermediate host of the parasite by the different frog species in the plantation [60].

Table 1. Prevalence and mean intensity of helminths in Aubra subsigillata and Hoplobatrachus occipitalis from cocoa plantations in Ojo camp, Ugboke.

\begin{tabular}{|c|c|c|c|c|}
\hline \multirow[b]{2}{*}{ Parasite } & \multicolumn{2}{|c|}{ Aubra subsigillata } & \multicolumn{2}{|c|}{ Hoplobatrachus occipitalis } \\
\hline & $\begin{array}{c}\text { Prevalence } \\
(\%)\end{array}$ & $\begin{array}{l}\text { Mean Intensity } \\
\quad \pm \text { S.D. }\end{array}$ & $\begin{array}{c}\text { Prevalence } \\
(\%)\end{array}$ & $\begin{array}{l}\text { Mean Intensity } \\
\quad \pm \text { S.D. }\end{array}$ \\
\hline \multicolumn{5}{|l|}{ Cestode } \\
\hline Proteocephalus larva sp. 3 & 18.2 & $14.5 \pm 19.09$ & - & - \\
\hline \multicolumn{5}{|l|}{ Digenea } \\
\hline M. aubriae & 9.1 & 5.0 & - & - \\
\hline M. micrurus & - & - & 9.1 & 1.0 \\
\hline Strigeiod trematode larva & 9.1 & 1.0 & - & - \\
\hline Mesocoelium sp. 1 & 9.1 & 10.0 & - & - \\
\hline Mesocoelium sp. 2 & 18.2 & $14.0 \pm 5.66$ & 9.1 & 6.0 \\
\hline Mesocoelium sp. 3 & 9.1 & 2.0 & - & - \\
\hline Mesocoelium sp. 4 & 18.2 & $10.0 \pm 11.31$ & - & - \\
\hline Mesocoelium sp. 5 & 9.1 & 10.0 & - & - \\
\hline Mesocoelium sp. 6 & 18.2 & $23.5 \pm 4.95$ & 9.09 & 6.0 \\
\hline \multicolumn{5}{|l|}{ Nematoda } \\
\hline Amplicaecum africanum & 9.1 & 1.0 & - & - \\
\hline Amplicaecum sp. & 9.1 & 1.0 & 9.1 & 4.0 \\
\hline Aplectana sp. & 9.1 & 1.0 & - & - \\
\hline Cosmocerca ornata & 9.1 & 7.0 & - & - \\
\hline Cosmocerca sp. & 9.1 & 2.0 & - & - \\
\hline Foleyellides sp. 3 & 9.1 & 2.0 & - & - \\
\hline Physaloptera sp. & 27.3 & $3.7 \pm 1.53$ & - & - \\
\hline
\end{tabular}

\section{Urbanization}

Urban landscapes in most of Africa are poorly planned; even when master plans exist, the provisions are in most cases not respected or adhered to. Therefore it is difficult to find cities where any refugia exist for the displaced animal fauna caused by urbanization.

As humans take down the natural vegetation, the resident fauna are forced to relocate to undeveloped plots, which may be unsuitable for their existence. Many species are undoubtedly lost in the process, but disturbance-tolerant species that succeed in finding alternative habitats thrive. It is on this crop of survivors that studies on parasite diversity have been undertaken.

\subsection{Urbanized Rainforest Environment}

Aisien et al. [62] investigated the helminth parasitic fauna of the anurans on the grounds of a University campus situated in an area that once was a thriving rainforest biotope; over time, this area became urbanized, with several changes to its natural ecology. The campus was adorned with ornamental trees and flower hedges; the lawns were frequently maintained. At night, anurans were sighted in drains, some shallow ponds and other water receptacles. Tree frogs abounded on the ornamental trees and tall grasses around the ponds. Our investigation revealed some interesting observations. Only nine anuran species tolerant of disturbed environments (Afrixalus fulvovitatus, Sclerophrys camerunensis, S. regularis, Hyperolius concolor (phases B and C), Hoplobatrachus occipitalis, Phrynobatrachus sp., Ptychadena pumilio and P. mascareniensis) thrived in this environment. Similarly, only a few parasite species were recorded in the anurans investigated. Of interest were the prevalence values recorded for some of the parasites. For example, a prevalence of $66.7 \%$ was recorded for the cestode Cylindrotaenia jagerskioeldi in Afrixalus fulvovittatus, caught on tall grasses around a pond in a swampy strip of the campus. This result contrasted sharply with the lower prevalence values $(0.24 \%$ and $12 \%)$ obtained for this cestode in hosts from other rainforest and derived savannah biotopes $[26,63]$. We observed that the 
altered environment had increased the population of the intermediate hosts (beetles) of the parasite. At night the beetles migrated to the grass tips, where the calling males of $A$. fulvovittatus were aggregated. This bottom-to-tip migration resulted in a disproportionate consumption of these beetles by male frogs, and hence a higher cestode prevalence in males (34.4\%) compared with females, which had only $7.14 \%$ prevalence. Infection intensity was also slightly higher in male frogs.

Also observed was an equally high prevalence of acanthocephalan cystacanths in some of the anurans: Hyperolius occidentalis (37.5\%), A. fulvovittatus (10.5\%), P. pumilio $(66.7 \%)$, S. regularis $(33.3 \%)$ and P. mascareniensis $(60.0 \%)$. This finding is noteworthy when compared with the overall prevalence value obtained for acanthocephalan cystacanths at the Okomu National Park, which stood at 14.4\% [39]. The prevalence of Chabaudus leberrei, transmitted by haematophagus insects such as mosquitoes, was equally high in H. occidentalis (37.5\%) when compared with the range of $2.4-8.3 \%$ in hosts from undisturbed forest biotopes [26,39].

\subsection{Urbanizing Rainforest}

Studies conducted in a changing rainforest biotope due to increasing urbanization and other anthropogenic activities [64] not only showed a drastic reduction in amphibian diversity (only six species) in the study area, but also recorded a high overall prevalence $(75 \%)$ and diversity (17) of parasites. Of particular interest among the helminth parasites recorded was an Ophidascaris sp. larva, which has been reported to use anurans as paratenic hosts in the rainforest and derived savannah biotopes of southern Nigeria [63]. The highest prevalence and infection intensity recorded was $20 \%$ and 10.3 parasites/infected host, respectively, in Ptychadena bibroni. Prevalence (P) and mean intensity (MI) values recorded in four anurans at Evbuabogun community [64] are as follows: S. maculata (P: 31.8\%, MI: 67.9); S. regularis (P: 50\%, MI: 1.0); P. oxyrhynchus (P: 50\%, MI: 13.1); P. pumilio (P: 33.3\%, MI: 1.0). Adults of this nematode have been recorded in snakes (Causus maculatus, Python regius and Loprophis fuliginosus) by Awharitoma et al. [65], some of which were caught at Evbuabogun. The unusually high mean intensity recorded in S. maculata (67.9) is indicative of an active transmission in the snake population within this altered habitat. According to Klingenberg [66], Ophidascaris infection in snakes adversely affects their reproductive ability. Odigwe [67] reported the occurrence of Ophidascaris larvae in the body cavity of Agama colonarum. It will be interesting to know the level of infection occurring in the Agama lizard from this community.

\section{Polluted Environments}

Oil industry activities in the Niger Delta of Nigeria have caused severe pollution, environmental degradation and reduced species richness, including those of amphibians, in their areas of operation [68-70]. One such impacted community is Ijala-Ikeren in Delta State, Nigeria, which is contiguous to the mangrove biotope in the Niger Delta. The measured $\mathrm{pH}$ in the interior of the mangrove creek ranged between 4.8 and 4.9 , and 5.3 to 6.1 in the backhouse ponds at the edges of the swamp [70,71]. These acidic conditions were caused by refinery effluents released from the Warri Refinery and Petrochemical Company (WRPC) on surface waters of the creek [72]. Other reported sources of pollution in the area are illegal toxic waste dump sites belonging to WRPC. These conditions not only impacted the amphibian richness of Ijala-Ikeren but also the parasite fauna of these frogs. From the nine anurans species collected from the community, 13 helminth parasite species were recovered. The depauperate assemblage of helminth species reflects the adverse environmental conditions confronting the free-living stages of parasites developing in this milieu. According to [29], the more the $\mathrm{pH}$ of an environment deviates from the speciesspecific optimum, the more it will affect the physiological properties of the free-living parasite stages, leading to impaired survival and/or reduced infectivity. For example, the Hoplobatrachus occipitalis caught from the acidic ponds were infected with only five helminth parasites, contrasting clearly with the same host collected from non-polluted 
locations in the rainforest and freshwater swamps [23] and in the derived savannah [24], where 12 to 13 parasites were recorded. This finding is similar, however, to those at the cocoa plantations at Ojo Camp, Ugboke [58], where only four helminth parasites were recorded. It is evident from these results that the prevailing acidic conditions in the ponds were unsuitable for parasite development and transmission. The tree frogs caught in this mangrove environment were no different. Parasites were only recovered from two species (A. dorsalis and H. concolor, phase C), while the others (A. fulvovittatus, Afrixalus sp., H. fusciventris burtoni, H. guttulatus and H. concolor phase B) harbored no parasites. This situation contrasts with findings at the Okomu National Park, where the tree frogs were infected with 13 helminth parasites, including cestodes, monogeneans, digeneans and nematodes, although at low infection intensity [73].

Another example of environmental pollution in the Niger Delta of Nigeria is the massive oil pollution in Ogoniland [69]. Despite these conditions, there appears to be some pockets of water bodies in which amphibians still thrive, from which locals harvest edible frog species to sell in local markets. Examination of three Ptychadena spp. (P. bibroni, P. pumilio and P. mascareniensis) purchased from Nyokhana, Ogoniland, yielded ten endoparasites [74]. Worthy of note is the pattern of infection with monogeneans in these frogs. The prevalence values obtained for the Polystoma spp. recorded were Polystoma baeri (75\%), Polystoma pricei (28\%) and Polystoma aeschlimanni (31.35\%). Surprisingly, these prevalence values were much higher than those recorded elsewhere in Niger Delta, where the environmental conditions were more suitable for polystome development and transmission [50]. For instance the prevalence and intensity of infection obtained for P. baeri in Nyokhana (Ogoniland) was much higher than what was reported from the unpolluted environment in Ase (12.5\%) reported by Aisien et al. [50]. Similarly, the prevalence and mean intensity of infection for P. pricei from Ogoniland $(28 \% / 2.14)$ was again higher than the $9.1 \% / 1.0$ recorded in Ase. It was only in the infection with Polystoma aeschlimanni in Ptychadena pumilio that a higher prevalence and infection intensity $(40 \% / 2.0)$ was recorded in Ase. We presume that the higher infections recorded in Ogoniland, despite the oil pollution and environmental degradation, were because frog tadpoles, confined to the few unpolluted ponds, were exposed to higher oncomiracidia density, leading to the higher prevalence values recorded.

\section{Amphibian Paratenism}

One phenomenon worthy of mention at this juncture is amphibian paratenism. Its importance lies in its role in the trophic transmission of helminth parasites to their final hosts.

According to Odening [75], paratenic hosts are intermediate hosts in which there is no larval growth or development. Sharpilo and Salamatin [76] defined paratenism as the ability of infective stages of several groups of parasitic organisms to settle and persist in organs and tissues of animals that are not suitable as definitive hosts. Larvae of parasites persisting in these hosts usually do not show obvious morphological changes, although sometimes they may grow and advance in their development. The paratenic hosts serve as an alternative source of infection for definitive hosts, but in some circumstances, due to environmental constraints, they may become an important, the main or even the only source of infection of definitive hosts [76]. Another view expressed by Santos and Amato [77] was that paratenic hosts act as a trophic bridge between the intermediate host and the definitive host, concentrating and passing the infective stage (e.g., cystacanths of acanthocephalans) to the definitive host.

A paper on hymenochirine anurans as transport hosts in camallanid nematode lifecycles by Jackson and Tinsley [22] reported the occurrence of different larval stages in the intestine and stomach of Pseudohymenochirus merlini in Sierra Leone. Imported Hymenochirus curtipes from Nigeria were reported to harbor third-stage procamallanine larvae. Comparable specimens were also found in the stomach of museum collections of $H$. boettiger from the Democratic Republic of Congo. It was concluded that predation of hymenochirines 
possibly presented an important transmission route for these parasites between copepod intermediate hosts and larger aquatic predators.

This paper prompted Imasuen et al. [63] to investigate anurans from the rainforest and derived savanna in southern Nigeria to determine their role as either intermediate or paratenic hosts of helminth infections. From the anurans examined, metacercariae of a strigeoid trematode, two nematode species, a proteocephalid cestode and an acanthocephalan cystacanth were recorded. The study showed that except for the strigeoid trematode, which was recorded only in the rainforest, the other parasites were represented in both biotopes. The two larval nematode species recorded in the body cavity of some Ptychadena spp. were believed to use them as paratenic hosts. The finding of acanthocephalan cystacanths in Ptychadena and Phrynobatrachus spp. from both biotopes confirmed their known role as paratenic hosts for acanthocephalans.

Other investigations thereafter revealed that the scope of amphibian paratenism is much wider than previously thought, and the following examples buttress this fact.

\subsection{Acathocephala}

These parasites are also referred to as spiny-headed worms. While adult worms have been reported in the intestinal tract of anurans in Brazil [78], Tanzania [79], China [80] and Madagascar [81], in the anurans studied in Nigeria, only cystacanths (Figure 2A-C) have been found attached to organs of the viscera, including the gastro-intestinal tract, the liver and the urinary bladder $[50,63,82]$. The amphibian hosts parasitized were diverse; they included terrestrial species (Sclerophrys regularis, S. maculata, Ptychadena spp., Phrynobatrachus liberiensis and P. plicatus, see [59]), tree frogs (Hyperolius fusciventris, H. fusciventris burtoni, H. picturatus, H. sylvaticus, Afrixalus dorsalis, A. nigeriensis, Chiromantis rufescens, Amnirana albolabris, Leptopelis spiritusnoctis) and the clawed toad, Silurana tropicalis (see $[63,81])$. The cysts occurred either singly or in pairs $[58,63,64]$, but in recent studies, cysts containing numerous cystacanths (60-70 larvae) in a cyst pack have been reported [62,83].

A
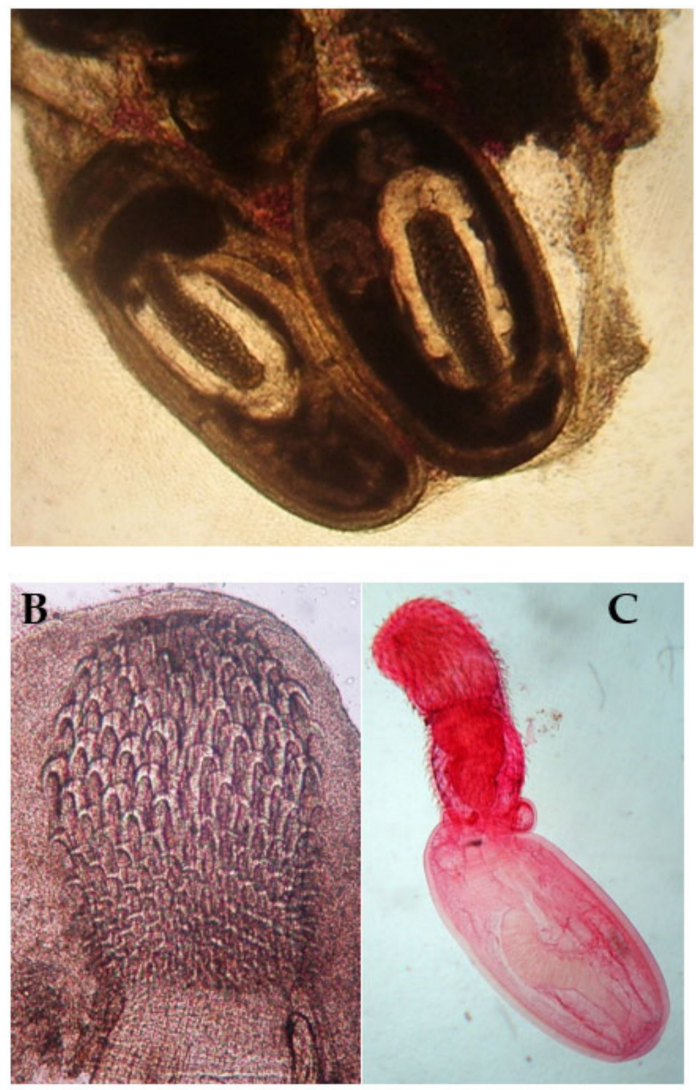

Figure 2. (A-C) Some acanthocephalan cystacanths recorded in anuran hosts from Nigeria. 
Aisien et al. [62] remarked that multiple cystacanth recorded in the urbanized tropical rainforest at Diobu-Port Harcourt represented a parasitic adaptation to ensure effective delivery of infective stages in an unstable environment. While this may be so, it is also possible that the presence of multiple cysts is a characteristic peculiar to that acanthocephalan species.

The definitive hosts of the acanthocephalan species using anurans as paratenic hosts in Nigeria are unknown. There are indications that some, especially those occurring in tree frogs, may be parasites of birds. Adults of several acanthocephalan species have been described from birds in Côte d'Ivoire [84-86] and one from Egypt [87].

\subsection{Cestoda}

These are segmented flatworms whose adults inhabit the intestinal tracts of various vertebrates, while the larval stages occur in various organs and tissues. They have an indirect cycle involving intermediate or paratenic hosts from which susceptible definitive hosts acquire infection.

Only three adult cestode species (Cephalochlamys compactus, Cylindrotaenia jaegerskioeldi and Nematotaenoides sp.) have been reported in anurans from Nigeria. Cephalochlamys compactus infects pipid anurans $[24,49,88]$ and Hoplobatrachus occipitalis (see [23,50,89]). Cylindrotaenia jaegerskioeldi occurs in a wider range of anuran hosts, including Afrixalus dorsalis, A. fulvovittatus, Sclerophrys maculata, S. regularis, Ptychadena bibroni, P. mascareniensis, P. oxyrhynchus and P. pumilio (see [23,24,50,57,58,62,71]). A recent addition to the group is a Nematotaenoides sp., which has been recorded in two tree frogs (Afrixalus dorsalis and Hyperolius fusciventris) and Ptychadena pumilio (see $[57,59,61,88])$.

\subsection{Proteocephalid Cestodes (Proteocephalus and Ophiotaenia spp.)}

Proteocephalid cestodes as adults are intestinal parasites of mostly teleost fish but also occur in amphibians and reptiles [90]. According to Rego [91], they are considered the most important parasites of Siluriforms (catfishes), in view of the number of species that have been described from this group. Proteocephalid cestodes are characterized by the presence of four muscular suckers on the scolex, which may possess an apical organ, an apical sucker and occasionally an armed rostellum [90,92].

In Nigeria, adult proteocephalid cestodes have so far not been recorded in anurans. Instead, encysted larval stages attached to different organs of the viscera are a common occurrence in different anuran taxa. Five different larval Protocephalus spp., with different scolex morphologies, have so far been recovered from anuran species collected in protected forests and a monoculture plantation. These include a Proteocephalus sp. (Figure 3A) recovered from Sclerophrys regularis, another Proteocephalus sp. (Figure 3B) from Arthroleptis poecilonotus (see [58]), a Proteocephalus sp. (Figure 3C) with a wide host range, including several tree frog spp., Ptychadena spp., Phrynobatrachus spp. and Silurana tropicalis (see $[49,59,62,64,71,93]$ ), a Proteocephalus sp. (Figure 3D) from Amnirana galamensis [50] and a Proteocephalus sp. (Figure 3E) from Hoplobatrachus occipitalis [83]. Further studies are needed to establish the definitive hosts of these proteocephalids. This will in no small measure bridge the information gap that still exists regarding these larval cestode species.

There is a recent report of an Ophiotaenia sp. larva (Figure 3F) recovered from the leaf litter frog, Arthroleptis poecilonotus (see [58]) from a cocoa plantation. Awharitoma et al. [65] reported an Ophiotaenia sp. in a viper (Causus maculatus) caught in a suburb of Benin City, Nigeria. This finding has shown that snakes are indeed the definitive hosts of these cestodes, thus confirming reports in other studies in Southern Rhodesia (now Zimbabwe), Cameroon and Madagascar [94-97]. Other snake species need to be examined with a view to establishing the species diversity and host range of Ophiotaenia species in Nigeria. 

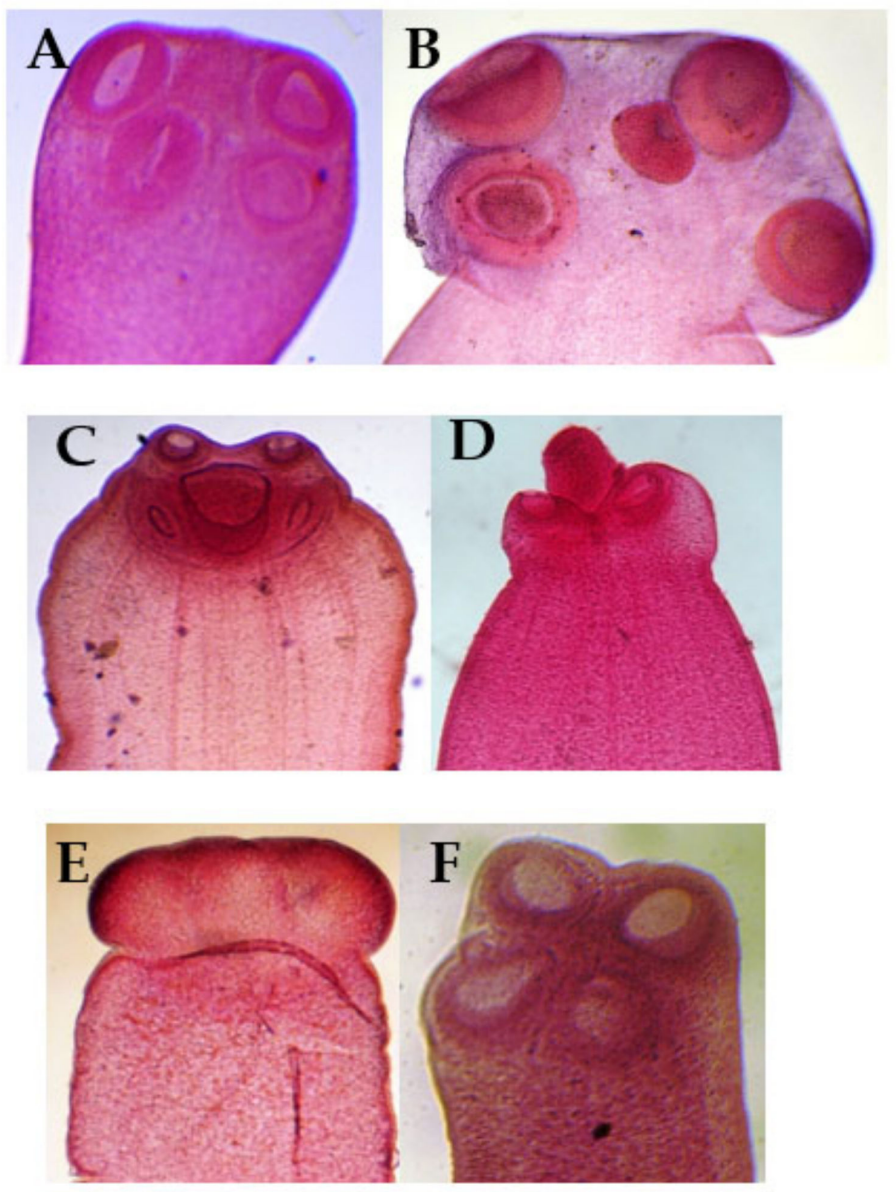

Figure 3. (A-F) Scoleces of larval cestodes encysted in the viscera of anuran hosts in Nigeria. (A) Proteocephalus sp. in S. regularis; (B) Proteocephalus sp. in Arthroleptis poecilonotus; (C) Proteocephalus sp. in Ptychadena bibroni, P. pumilio, P. mascareniensis, H. occipitalis, S. tropicalis and several tree frogs; (D) Proteocephalus sp. in A. galamensis; (E) Proteocephalid cestode in H. occipitalis; (F) Ophiotaenia sp. in A. poecilonotus.

\subsection{Oochoristica}

Oochoristica species are cyclophyllidean cestodes whose distribution is cosmopolitan; they are parasitic mainly in reptilian hosts [98] but occasionally in mammals [99]. Adults of Oochoristica species reported in reptilian hosts from Africa include O. beveridgei, O. crassiceps (syn. O. sigmoides, O. fusca), O. jonnesi, O. koubeki, O. theileri, O. truncata (syn, Taenia truncata, Krabbe, 1879; O. agamae Baylis, 1919; O. africana Malan, 1939; O. africana var. ookispensis), and O. uberlakeri (see [98]). Oochoristica agamae also has records in two bat species [99].

The occurrence of Oochoristica spp. among amphibians is uncommon. Until recently, the only known case was the report of O. truncata in Hoplobatrachus occipitalis by Southwell and Lake [100] in Belgian Congo. These specimens were most probably adult specimens, which made identification possible. The second report of Oochoristica in anurans was by Aisien and Igetei [101] in S. maculata and P. oxyrhynchus (Figure 4A-D). These specimens were juveniles with mature proglottids but lacking the gravid, which would have been an indicator of reproductive success in these anurans and qualify them as definitive hosts. The lack of gravid proglottids meant that $S$. maculata and $P$. oxyrhynchus play a different role in the biology of these cestodes. These anurans serve as transport (paratenic) hosts in the trophic transfer of these immatures to their definitive hosts (possibly snakes), where they attain full maturity and reproduction. 


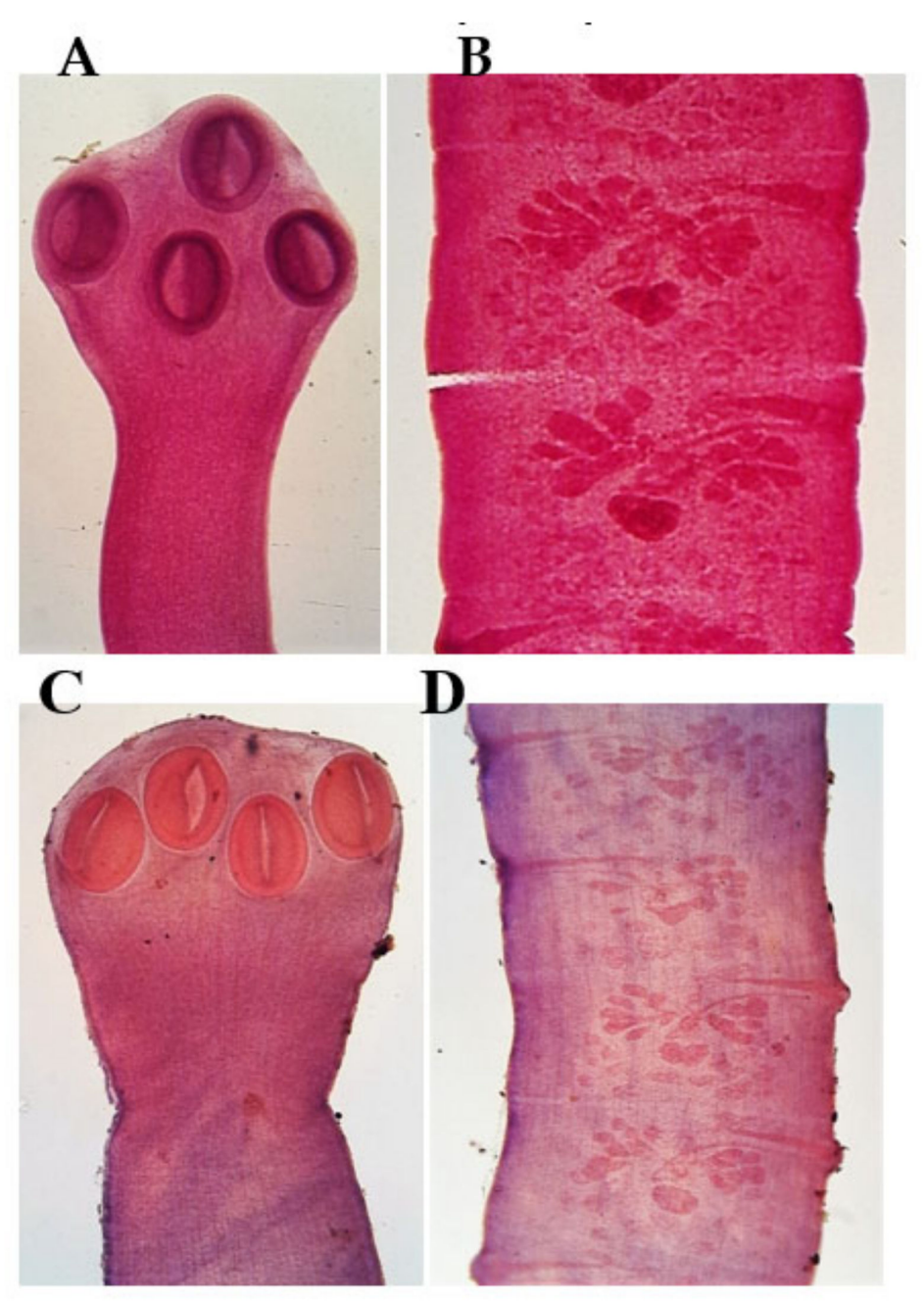

Figure 4. (A-D) Oochoristica sp. infecting anurans: (A,B) scolex and mature proglottid of parasite infecting Sclerophrys maculata; (C,D) scolex and mature proglottid infecting Ptychadena oxyrhynchus.

\subsection{Diplopylidium}

Members of the genus Diplopylidium are small- to medium-sized intestinal cestode parasites of carnivores [102-105]. The scolex has an apically flattened rostellum, armed with crowns of hooks and four cuplike suckers (Figure 5A,B). Cysts containing the cysticercoids of this parasite were recorded in three anuran hosts (Phrynobatrachus calcaratus, Sclerophrys maculata and Ptychadena mascareniensis) in locations within a rainforest biotope in southern Nigeria [60]. The cysts occurred in the liver parenchyma of $P$. calcaratus but were attached to the intestinal mesentery of S. maculata (Figure 6) and P. mascareniensis. The highest prevalence of $27.3 \%$ was recorded in P. calcaratus, but the highest infection intensity of 69 cysticercoids/infected host occurred in P. mascareniensis. Imasuen and Aisien [82] also recorded the cysticercoids of this parasite in $P$. mascareniensis in another location but with lower infection intensity (1.0 cysticercoid/infected host).

Ptychadena mascareniensis is a new addition to the list of paratenic hosts of $D$. triseriale in West Africa. In an earlier report by Baer [106], Sclerophrys maculata, Phrynobatrachus accraensis and P. calcaratus were reported to play this role in Côte d'Ivoire. While Aisien et al. [60] reported that Civetticus civetta, the African civet, as the definitive host of the parasite in their study location, further studies have shown that the African Palm Civet (Nandinia binotata) is also host to this parasite [107]. 


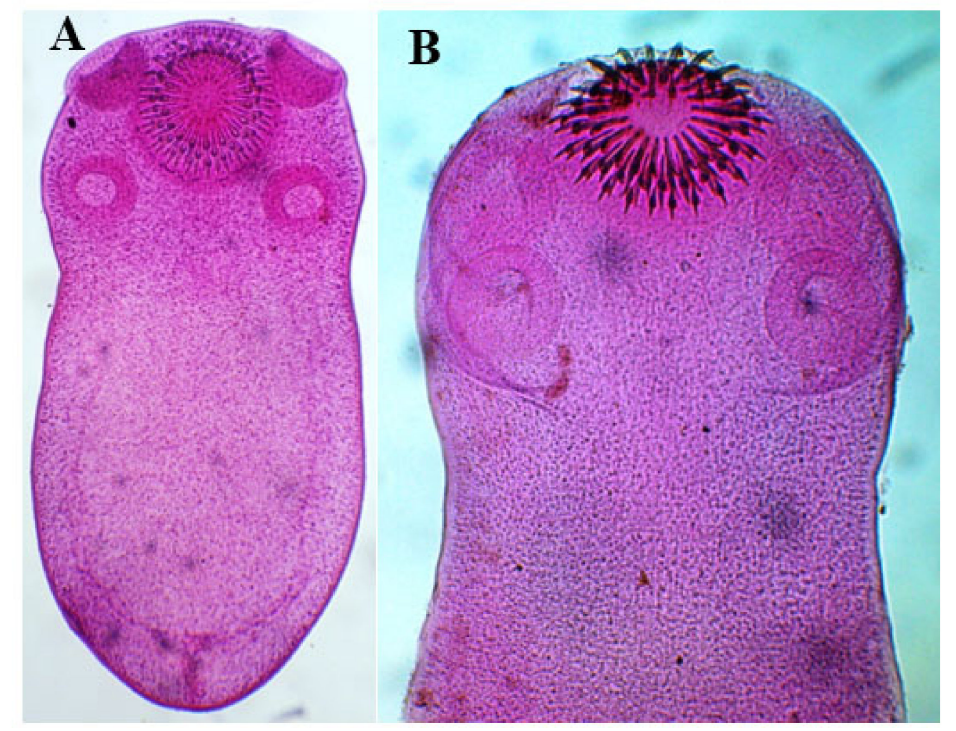

Figure 5. (A,B) Rostellum of Diplopylidium triseriale showing hooks and suckers in (A) cysticercoid and (B) adult parasite.

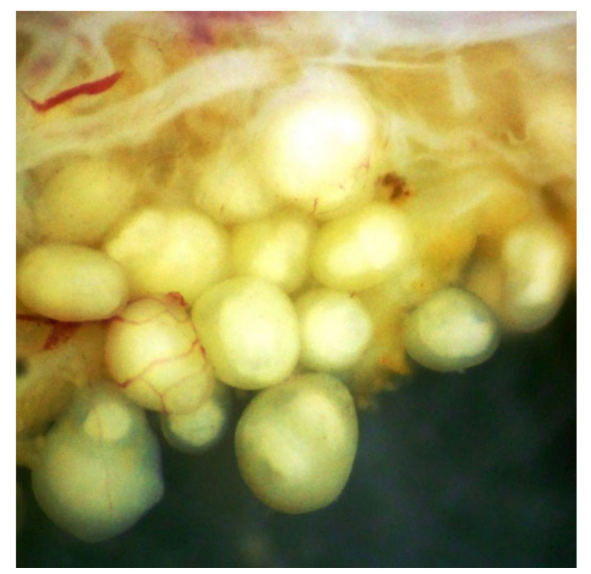

Figure 6. Cysts containing the cysticercoids of D. triseriale attached to the intestinal mesentery of S. maculata.

\subsection{Larval Nematodes}

Nematodes are considered to be one of the largest invertebrate groups, second only to the phylum Arthropoda. Some are free-living, while others are parasitic, either in animals or in plants. While many species have anurans as their definitive hosts [23-26,49,50,62,71,74,81], a number of them utilize anurans as paratenic hosts. Chief among them are larval ascaridoids (Figure 7A,B), which have been encountered in a variety of anuran hosts. The Ophidascaris larva (Figure 7A) has been recovered from several anuran species $[24-26,49,50,60,62,63,71,83,94]$ and Agama colonarum (see [67]). Adults of this nematode were recovered from snakes in Benin City, Nigeria, by Awharitoma et al. [65]. The second ascaridoid larva (Figure 7B) is yet to be identified; it occurs encysed in the stomach mucosa of H. occipitalis in the Niger Delta of Nigeria [50,71]. A third encysted nematode larva (Figure 7C), with a semi-transparent cyst, was recovered from nine anurans in the rainforest and two in the derived savannah [63]. Although this parasite had a wide host range, the prevalence and infection intensity were generally low. 


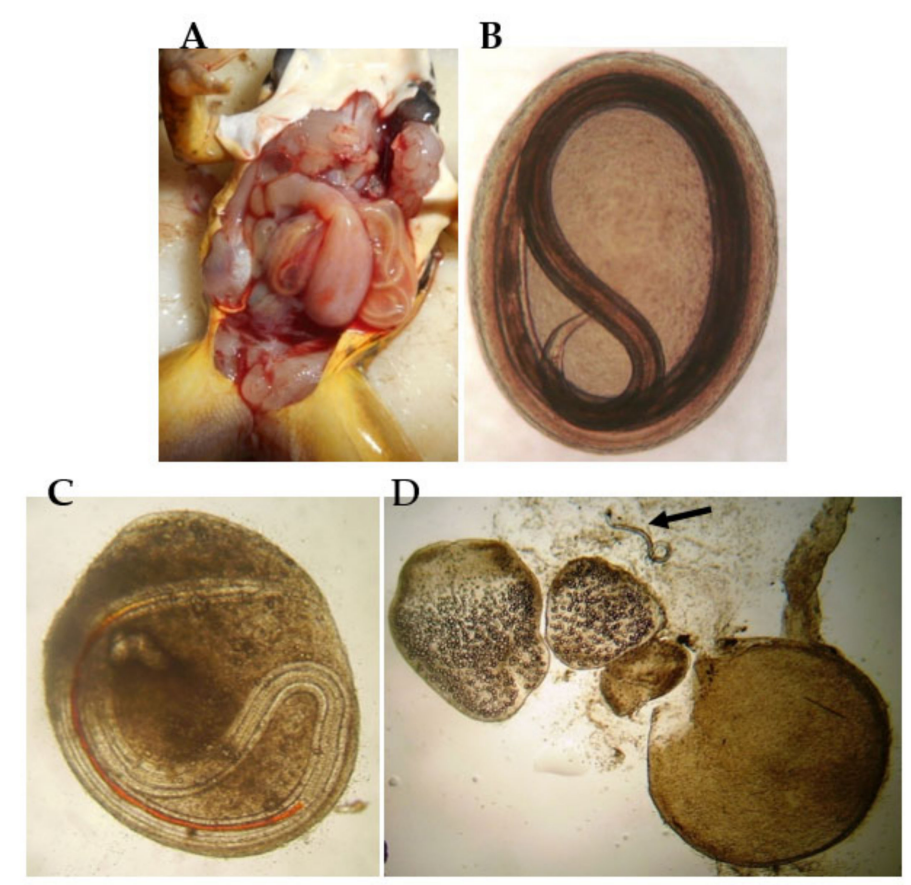

Figure 7. (A-D) Some nematode cysts occurring in anurans; (A,B) Ascaridod larvae in the body cavity of $P$. pumilio and stomach mucosa of $H$. occipitalis, respectively; (C) larva of an unidentified nematode infecting several anuran species; (D) an unidentified nematode larva occurring as mixed infection with Proteocephalus sp. larvae in a cyst recovered from S. tropicalis.

A novel situation was observed in the co-occurrence of a nematode larva with larvae of a Proteocephalus sp. in a cyst (Figure 7D) recovered from the body cavity of S. tropicalis [49]. Mixed infection of this nature provides parasites with efficient delivery mechanism of multiple infections to their definitive hosts. This certainly represents an interesting adaptation for parasitic existence among these parasites.

\section{Conclusions}

Diverse scenarios play out in the ecological biotopes of West Africa, and these have their peculiar influence on the parasite diversity in the amphibians of these habitats. Pristine or protected habitats in forest reserves, national parks, freshwater swamps and creeks tend to harbor higher amphibian diversity. Parasite diversity is high and prevalence is moderate, with low infection intensity, showing some balance in the host-parasite relationship.

In environments altered by agricultural practices coupled with pesticide and herbicide use, prevalence tended to be high, while infection intensity was generally low. Higher parasite prevalence is attributed to the immunosuppressive effects of agrochemicals, while the low infection intensity is ascribed to the inhibitory effects of these chemicals to the development of the free-living larval stages of parasites. Pollution due to oil industry activities in the Niger Delta of Nigeria occurs over vast areas. Nevertheless, there are still some water bodies in these areas that sustain amphibian life. Host sequestration in these water bodies exposed amphibian tadpoles to high loads of polystome oncomiracidia, resulting in high prevalence values that were not recorded in non-polluted habitats. Acidic $\mathrm{pH}$ conditions in the mangrove swamps and ponds also limit parasite diversity, prevalence and infection intensity.

Changes due to urbanization not only negatively impact anuran host diversity, they also alter the pattern of infection for some parasites, increasing prevalence and infection intensity values.

Amphibian paratenism appears to be widespread among anurans in Nigeria, where it plays an important role in the biology of many helminth parasites. There is a need to 
further investigate this phenomenon, with the view to establishing the definitive hosts of parasite species trophically transferred via this infection route.

Author Contributions: Conceptualization, M.S.O.A., O.E.-T. and A.A.I.; methodology, M.S.O.A.; software, M.S.O.A.; validation, M.S.O.A.; formal analysis, M.S.O.A., investigation, M.S.O.A., O.E.-T. and A.A.I.; resources, M.S.O.A., O.E.-T. and A.A.I.; data curation, M.S.O.A., O.E.-T. and A.A.I.; writing-original draft preparation, M.S.O.A., O.E.-T. and A.A.I.; writing-review and editing, M.S.O.A. and O.E.-T.; visualization, M.S.O.A.; supervision, M.S.O.A. and project administration, M.S.O.A. All authors have read and agreed to the published version of the manuscript.

Funding: This research received no external funding.

Institutional Review Board Statement: Ethical review and approval was not required, but we always followed the Guidelines for Ethical Conduct in the Care and Use of Nonhuman Animals in Research by the American Psychological Association.

Informed Consent Statement: Not applicable.

Data Availability Statement: Data sharing not applicable to this article.

Conflicts of Interest: The authors declare no conflict of interest.

\section{References}

1. Dollfus, R.-P. Contribution à d'Etude de la Faune du Cameroun par Th. Monod (fasc. 2) Helmintha I Trematoda et Acanthocephala. Faune Colonies Françaises 1929, 3, 73-114.

2. Maeder, A.-M. Trématodes de Batraciens de Côte d'Ivoire. Rev. Suisse Zool. 1969, 76, 903-918. [CrossRef] [PubMed]

3. Maeder, A.-M. Monogènes et Trématodes parasites d'Amphibiens en Côte d'Ivoire. Rev. Suisse Zool. 1973, 80, 267-322. [CrossRef]

4. Maeder, A.-M.; Combes, C.; Knoepffler, L.-P. Parasites d'Amphibiens du Gabon: Plagiorchiidae et Parmaphistomatidae (Digenea). Biol. Gabonica 1969, 5, 283-288.

5. Maeder, A.-M.; Combes, C.; Knoepffler, L.-P. Parasites d'Amphibiens du Gabon: Mesocoelidae (Digenea). Taxonomie et chorologie du genre Mesocoelium Odhner, 1911. Biol. Gabonica 1969, 5, 289-303.

6. Maeder, A.-M.; Combes, C.; Knoepffler, L.-P. Parasites d'Amphibiens de Côte d'Ivoire: Plagiorchidae et Mesocoelidea (Digenea). Biol. Gabonica 1970, 6, 387-393.

7. Maeder, A.-M.; Combes, C.; Knoepffler, L.-P. Parasites d'Amphibiens de Republique Centrafricaine: Plagiorchiidae et Mesocoelidae (Digenea). Biol. Gabonica 1970, 6, 395-402.

8. Durette-Desset, M.-C.; Batcharov, G. Duex Nématodes parasites d'Amphibiens du Togo. Ann. Parasitol. Hum. Comp. 1974, 46, 567-576. [CrossRef]

9. Durette-Desset, M.-C.; Vaucher, C. Etude d'une collection de nematodes parasites d'amphibiens du Cameroun I. Trichostrongyloidea (Nematoda). Rev. Suisse Zool. 1979, 86, 509-525. [CrossRef]

10. Gassmann, M. Contribution à l'etude des Trématodes d'Amphibiens du Cameroun. Ann. Parasitol. Hum. Comp. 1975, 50, 559-577. [CrossRef]

11. Bourgat, R.; Dossou, C.; Gasc, C. Trematodes d'Amphibiens du Sud Benin. Description de Gorgoderina beninensis n. sp. Ann. Univ. Benin. Togo. 1976, 2, 63-68.

12. Bourgat, R.; Roure, C.; Kulo, S.-D. Nouvelles données sur les Trématodes d'Amphibiens d'Afrique Occidentale. Description d'Haematoloechus aubriae n. sp. Rev. Suisse Zool. 1996, 103, 383-394. [CrossRef]

13. Saoud, M.F.A. On some digenetic trematodes (Mesocoelium spp.) from Amphibia and Reptilia of the Cameroons. J. Helminthol. 1964, 3/4, 291-302. [CrossRef]

14. Fischthal, J.D. Some digenetic trematodes of anurans from Central and West Africa. Rev. Zool. Afric. 1977, 91, 117-130.

15. McAllister, C.T.; Bursey, C.R.; Freed, P.S. Helminth parasites (Cestoidea, Nematoda, Pentastomida) of selected herpetofauna from Cameroon, West Africa. Acta Parasitol. 2011, 55, 90-93. [CrossRef]

16. Daniel, N.N.; Josue, W.P.; Mbida, M. Gastro-intestinal helminths of goliath frogs (Conraua goliath) from localities of Loum, Yabassi and Nkondjock in the Littoral Region of Cameroon. Glob. Ecol. Conserv. 2015, 4, 146-149. [CrossRef]

17. Rees, G. Two new species of the genus Haematoloechus (Digenea: Plagiorchiidae) from Rana occipitalis (Gunther) in Ghana. Parasitology 1964, 54, 345-368. [CrossRef]

18. Fischthal, J.H.; Thomas, J.D. Digenetic trematodes of amphibians and reptiles from Ghana. Proc. Helminthol. Soc. Wash. 1968, 35, $1-15$.

19. Jackson, J.A.; Tinsley, R.C. Representatives of Batrachocamallanus n.g. (Nematoda: Procamallaninae) from Xenopus spp. (Anura: Pipidae): Geographical distribution, host range and evolutionary relationships. Syst. Parasitol. 1995, 31, 159-188. [CrossRef]

20. Jackson, J.A.; Tinsley, R.C. Evolutionary relationships, host range and geographical distribution of Camallanus Railliet and Henry, 1915 species (Nematoda: Camallaninae) from clawed toads of the genus Xenopus (Anura: Pipidae). Syst. Parasitol. 1995, 32, 1-21. [CrossRef] 
21. Jackson, J.A.; Tinsley, R.C. Paramphistome digeneans from Xenopus species (Pipidae) in Africa: Taxonomy, host specificity and biogeography. Syst. Parasitol. 1998, 40, 143-160. [CrossRef]

22. Jackson, J.A.; Tinsley, R.C. Hymenochirine anurans (Pipidae) as transport hosts in camallanid nematode life-cycles. Syst. Parasitol. 1998, 39, 141-151. [CrossRef]

23. Aisien, S.O.; Ugbo, A.D.; Ilavbare, A.N.; Ogunbor, O. Endoparasites of amphibians from south western Nigeria. Acta Parasitol. 2001, 46, 299-305.

24. Aisien, S.O.; Ajakaiye, F.B.; Braimoh, K. Helminth parasites of anurans from the savanna-mosaic zone of south western Nigeria. Acta Parasitol. 2003, 48, 47-54.

25. Aisien, S.O.; Ayeni, F.; Ilechie, I. Helminth fauna of anurans from the Guinea savanna at New Bussa, Nigeria. Afr. Zool. 2004, 39, 133-136.

26. Aisien, M.S.O.; Ogoanah, S.O.; Imasuen, A.A. Helminth parasites of amphibians from a rainforest reserve in southwestern Nigeria. Afr. Zool. 2009, 44, 1-7. [CrossRef]

27. Lafferty, K.D. Environmental Parasitology: What can parasites tell us about human impacts on the environment? Parasitol. Today 1997, 12, 251-255. [CrossRef]

28. Kiesecker, J.M. Synegism between trematode infection and pesticide exposure: A link to amphibian limb deformities in nature? Proc. Natl. Acad. Sci. USA 2002, 99, 9889-9904. [CrossRef] [PubMed]

29. Pietrock, M.; Marcogliese, D.J. Free-living endohelminth stages: At the mercy of environmental conditions. Trends Parasitol. 2003, 19, 293-299. [CrossRef]

30. Christin, M.S.; Ménard, L.; Gendron, A.D.; Ruby, S.; Cyr, D.; Marcogliese, D.J.; Rollins-Smith, L.; Fournier, M. Effects of agricultural pesticides on the immune system od Xenopus laevis and Rana pipiens. Aquat. Toxicol. 2004, 67, 33-43. [CrossRef]

31. Sures, B. Environmental parasitology: Relevancy of parasites in monitoring environmental pollution. Trends Parasitol. 2004, 20, 170-177. [CrossRef] [PubMed]

32. Marcogliese, D.J. Parasites: Small players with crucial roles in the ecological theatre. EcoHealth 2004, 1, 151-164. [CrossRef]

33. McKenzie, V.J. Human land use and patterns of parasitism in tropical amphibian hosts. J. Bioconserv. 2007. [CrossRef]

34. Johnson, P.T.J.; Chase, J.M.; Dosch, L.; Hartson, R.B.; Gross, J.A.; Larson, D.J.; Sutherland, D.R.; Carpenter, S.R. Aquatic eutrophication promotes pathogenic infection in amphibians. Proc. Natl. Acad. Sci. USA 2007, 108, 15781-15786. [CrossRef]

35. Rohr, J.R.; Raffel, T.R.; Sessions, S.K.; Hudson, P.J. Understanding the net effects of pesticides on amphibian trematode infections. Ecol. Appl. 2008, 18, 1743-1753. [CrossRef]

36. Rohr, J.R.; Schotthoefer, A.M.; Raffel, T.R.; Carrick, H.J.; Halstead, N.; Hovermann, J.T.; Johnson, C.M.; Johnson, L.B.; Lieske, C.; Piwoni, M.D.; et al. Agrochemicals increase trematode infections in a declining amphibian species. Nature 2008, 455, 1235-1239. [CrossRef]

37. King, K.C.; McLaughlin, J.D.; Boily, M.; Marcogliese, D.J. Effects of agricultural landscape and pesticides on parasitism in native bullfrogs. Biol. Conserv. 2010, 143, 302-310. [CrossRef]

38. Meijaard, E.; Douglas, S.; Robert, N.; Augeri, D.; Rosenbaum, B.; Iskandar, D.; Setyawati, T.; Lammertink, M.; Rachmatika, I.; Wong, A.; et al. Life after Logging: Reconciling Wildlife Conversation and Production Forestry in Indonesian Borneo; Centre for International Forestry (CIFOR): Bogor, Indonesia, 2005; 346p.

39. Imasuen, A.A. Investigation of Helminth Parasitic Infections and Chytridiomycosis of Amphibians in Okomu National Park, Nigeria. Ph.D. Thesis, University of Benin, Benin City, Nigeria, 2011.

40. Aisien, M.S.O.; Du Preez, L.H.; Imasuen, A.A. Polystoma okomuensis n.sp. (Monogenea: Polystomatidae) from Boulenger's striped frog, Phlyctimantis boulengeri (Perret, 1986) in Nigeria. J. Helminthol. 2011, 85, 153-159. First published online 30 July 2010. [CrossRef]

41. Saoud, M.F.A. On Polystoma prudhoei sp. nov (Trematoda: Monogenea) from Rana (Ptychadena) oxyrhynchus in the Cameroons. J. Helminthol. 1967, 41, 229-239. [CrossRef]

42. Euzet, L.; Combes, C.; Knoepffler, L.-P. Parasites d'Amphibiens de la Centrafricaine. Polystomatidae (Monogenea). Vie Millieu 1974, 24, 141-150.

43. Tinsley, R.C. Observations on Polystoma africanum Szidat with a review of the inter-relationships of Polystoma species in Africa. J. Nat. Hist. 1974, 8, 355-367. [CrossRef]

44. Dupouy, J.; Knoepffler, L.-P. Polystoma chiromantis n. sp. (Monogenea) chez Chiromantis rufescens (Günther, 1868) du Cameroun, du Gabon et de Cenrafrique. Bull. Mus. Nat. Hist. Nat. Paris Zool. 1978, 353, 217-220.

45. Murith, D.; Miremad-Gassmann, M.; Vaucher, C. Contribution à l'etudes Polystomes d'Amphibiens du Cameroun. Rev. Suisse Zool. 1978, 85, 681-698. [CrossRef]

46. Bourgat, R.; Murith, D. Polystoma lamottei n.sp. et Polystoma aeschlimanni n. sp. duex Polystomes (Monogènes) de la meme espèce d'Amphibien: Ptychadena pumilio (Boulenger, 1920). Z. Parasitenkd. 1980, 62, 293-301. [CrossRef]

47. Murith, D. Contribution à l'etude de la Sytématique des Polystomes (Monogènes: Polymatidae) parasites d'Amphibiens Anoures de basse Côte d'Ivoire. Rev. Suisse. Zool. 1981, 88, 475-503. [CrossRef]

48. Kulo, S.-D. Présence au Togo de Metapolystoma cachani (Gallien, 1957) Combes, 1976 (Monogenea) chez l'Amphibien Ptychadena longirostris (Peter, 1870). Bull. Soc. Zool. Fr. 1981, 106, 177-181.

49. Imasuen, A.A.; Aisien, M.S.O. Helminth parasites of Silurana tropicalis from the Okomu National Park, Edo State, Nigeria. Niger. J. Parasitol. 2015, 36, 61-66. 
50. Aisien, M.S.O.; Ugbomeh, A.P.; Awharitoma, A.O. Parasitic infections from a freshwater creek community in Delta State, Niger Delta of Nigeria. Helminthologia 2017, 54, 132-144. [CrossRef]

51. Anele, E.U.; Nock, I.H.; Gadzama, I.M.K. Helminth parasites of anurans from Zaria, northern Guinea savannah zone of Nigeria. Niger. J. Parasit. 2020, 41, 205-211. [CrossRef]

52. Combes, C.; Bourgat, R.; Salami-Cadoux, L. Biologie des Polystomatidae: Le cycle interne direct chez Eupolystoma alluaudi (de Beauchamp, 1913). Z. Parasitenkd. 1973, 42, 69-75. [CrossRef]

53. Aisien, M.S.O.; Nagos, S.G.; Roedel, M.-O. Parasitic infections of amphibians in the Pendjari Biosphere Reserve, Bénin. Afr. Zool. 2011, 46, 340-349. [CrossRef]

54. Johnson, P.T.J.; Chase, J.M. Parasites in the food web: Linking amphibian malformation and aquatic eutrophication. Ecol. Lett. 2004, 7, 521-526. [CrossRef]

55. Edo-Taiwo, O. Amphibian Diversity and Parasitic Infections in Relation to Pesticide Exposure at Ugboke (Plantations and Settlement), Ovia South-West LGA, Edo State, Nigeria. Ph.D. Thesis, University of Benin, Benin City, Nigeria, 2019.

56. Texeira, R.I.; Ferreira, R.B.; Silva-Soares, T.; Mageski, M.M.; Pertiel, W.; Rödder, D.; Hoffman de Barros, D.; Engler, J.O. Anuran community of a cocoa agro-ecosystem in southern Brazil. Salamandra 2015, 51, 1-4.

57. Edo-Taiwo, O.; Aisien, M.S.O. Helminth parasitic infections of leaf-litter frogs (Arthroleptis and Phrynobatrachus spp.) from cocoa plantations in southern Nigeria. Niger. J. Parasitol. 2020, 41, 93-100. [CrossRef]

58. Edo-Taiwo, O.; Aisien, M.S.O. Parasitofauna of ground-dwelling anurans from cocoa plantations in Ugboke, Edo State, Nigeria. Zoologist 2020, 18, 8-18. [CrossRef]

59. Ovwah, E. Amphibian Diversity and Helminth Parasitic Infections of Anurans at Okomu Oil Palm Plantations, Okomu-Udo, Edo State, Nigeria. Ph.D. Thesis, University of Benin, Benin City, Nigeria, 2016.

60. Aisien, M.S.O.; Agbosua, E.; Imasuen, A.A.; Daniel, O.S. Paratenic and definitive hosts of Diplopylidium triseriale from a southern Nigeria rainforest biotope. Zoologist 2017, 15, 50-55.

61. Agbosua, E. Helminth Parasites of Anurans in High Conservation Value Areas (HCVAs) in Okomu Oil Palm Plantation (Extension II) in Edo State, Nigeria. Master's Thesis, University of Benin, Benin City, Nigeria, 2019.

62. Aisien, M.S.O.; Sampson, S.A.; Amuzie, C.C. Parasitic infections of anurans from an urbanized rainforest biotope in Diobu, Port Harcourt, Nigeria. Niger. J. Parasitol. 2017, 38, 292-297. [CrossRef]

63. Imasuen, A.A.; Ozemoka, H.J.; Aisien, M.S.O. Anurans as intermediate and paratenic hosts of helminth infections in the rainforest and derived savanna biotopes of southern Nigeria. Int. J. Zool. 2012, 2012, 823970. [CrossRef]

64. Edo-Taiwo, O.; Omiunu, O.P.; Jibunor, R.O.; Ehiagwina, J.C.; Aisien, M.S.O. Endoparasites in six anurans from a changing rainforest biotope in Edo State, Southern Nigeria. Niger. J. Parasitol. 2020, 41, 251-259. [CrossRef]

65. Awharitoma, A.O.; Ehiorobo, U.A.; Edo-Taiwo, O. Snake species and their parasitic infections in Benin City, Nigeria. NJAFE 2017, 13, 158-162.

66. Klingenberg, R.J. Understanding Reptile Parasites: A Basic Manual for Herpetoculturists and Veterinarians; The Herpetocultural Library, Special Edition; Advanced Vivarium Systems: Lakeside, CA, USA, 1993; 81p.

67. Odigwe, F.W. Survey of Helminth Parasites Infecting Lizards in Benin City, Nigeria. Bachelor's Thesis, University of Benin, Benin City, Nigeria, 1985.

68. Akani, G.C.; Politano, E.; Luiselli, L. Amphibians recorded in forest swamp areas of the River Niger delta (southeastern Nigeria), and the effects of habitat alteration from oil industry development on species richness and diversity. Appl. Herpetol. 2004, 2, 1-22.

69. United Nations Environmental Program (UNEP). Assessment of Ogoniland; United Nations: New York, NY, USA, 2011; pp. 110-200.

70. Uwagbae, M.A.; Dirisu, A.R.; Gbarakoro, T.N.; El Surtasi, E.I.; Agwu, J.E.; Aisien, M.S.O.; Rotimi, J. Impact of disturbances on the biodiversity of Ijala-Ikeren wetland Ecosystem in Nigeria Niger Delta. In Mass Extinctions, Biodiversity and Global Problems; Hufnagel, L., Ed.; IntechOpen Ltd.: London, UK, 2019; pp. 1-20.

71. Aisien, M.S.O.; Uwagbae, M.; Edo-Taiwo, O.; Imasuen, A.A.; Ovwah, E. Pattern of parasitic infections in anurans from a mangrove community of the Niger Delta, Nigeria. Zoologist 2015, 13, 50-55.

72. Nduka, J.K.; Orisakwe, O.E. Effect of effluents from the Warri Refinery Petrochemical Company (WRPC) on water and soil qualities of "contiguous host" and "impacted communities" of Delta State. Open Environ. Poll. Toxicol. J. 2009, 1, 11-17. [CrossRef]

73. Imasuen, A.A.; Enabulele, E.E.; Aisien, M.S.O. Helminth community of tree frogs at the Okomu National Park, Edo State, Nigeria. Niger. J. Parasitol. 2012, 33, 1-8.

74. Amuzie, C.C.; Aisien, M.S.O. Parasitic helminths of some Ptychadena species from Ogoniland, Niger Delta, Nigeria. NISEB J. 2018, $18,68-74$.

75. Odening, K. Conception and Terminology of Hosts in Parasitology. Adv. Parasitol. 1976, 14, 1-93.

76. Sharpilo, V.P.; Salamatin, R.V. Paratenic Parasitism: Origins and Development of the Concept. Historical Essays, Bibliography; Schmalhausen Institute of Zoology, National Academy of Sciences: Kiev, Ukraine, 2005; pp. 235-238.

77. Santos, V.G.T.; Amato, S.B. Rhinella fernandezae (Anura, Bufonidae) a paratenic host of Centrorhynchus sp. (Acanthocephala, Centrorhychidae) in Brazil. Rev. Mex. Biodivers. 2010, 81, 53-56.

78. Bursey, C.R.; Vrcibradic, D.; Hatano, F.H.; Rocha, C.F.D. New genus, new species of Acanthocephala (Echinorynchidae) from the Brazilian frog Hylodes phyllodes (Anura: Leptodactylidae). J. Parasitol. 2006, 92, 353-356. [CrossRef]

79. Smales, L.R. Acanthocephalans from some frogs and toads (Anura) and Chameleons (Squamata) from Tanzania with the description of a new species. J. Parasitol. 2005, 91, 1459-1464. [CrossRef] 
80. Bush, S.E.; Duszynski, D.W.; Nickol, B.B. Acanthocephalans from amphibians in China with descriptions of new species of Pseudoacanthocephalus (Echinorhynchida). J. Parasitol. 2009, 95, 1440-1445. [CrossRef]

81. Golvan, Y.-J.; Brygoo, E.-R.; Gassmann, M. Acanthocephalus domerguei n. sp., parasite d'un Amphibien malgache. Ann. Parasitol. (Paris) 1972, 47, 305-308. [CrossRef]

82. Imasuen, A.A.; Aisien, M.S.O. Helminth parasitofauna of five Ptychadena species from altered rainforest biotopes in Edo State, Nigeria. Niger. J. Parasitol. 2019, 40, 193-197. [CrossRef]

83. Oghenekume, L.M. A Survey of the Parasites of Some Ranid Frogs from Emevor, Delta State Nigeria. Bachelor's Thesis, University of Benin, Benin City, Nigeria, 2016.

84. Smales, L.R. Plagiorhynchidae (Acanthocephala) including the description of a new species from birds from the Republic of Côte d'Ivoire, Africa. Rev. Suisse Zool. 2010, 117, 153-158.

85. Smales, L.R. Centrorhynchidae (Acanthocephala) including the description of new species of Centrorhynchus from birds in Côte d'Ivoire, Africa. Rev. Suisse Zool. 2011, 118, 307-318. [CrossRef]

86. Smales, L.R. Gigantorhynchidae (Acanthocephala) including the description of new species of Mediorhynchus from birds from Côte d'Ivoire, Africa. Comp. Parasitol. 2011, 78, 316-326. [CrossRef]

87. Ashmawy, K.I.; El-Sokkary, M.Y. Morphological studies on a Pseudoporrorchis species (Acanthocephala); infecting the Egyptian cuculus (Centropus senegalensis aegyptius). Assiut Vet. Med. J. 1991, 25, 98-107.

88. Imasuen, A.A.; Ifije, L.E.; Alari, E.; Agbosua, E.; Aigbirior, P.O.; Aisien, M.S.O. Helminth parasites of anurans from Iguedo-Okada, a peri-urban rainforest biotope in Edo State, Nigeria. Niger. J. Life Sci. 2019, 8, 111-120.

89. Jackson, J.A.; Tinsley, R.C. Host specificity and distribution of cephalochlamid cestodes: Correlation with allopolyploid evolution of pipid anuran hosts. J. Zool. 2001, 254, 405-419. [CrossRef]

90. Scholz, T.; De Chambrier, A. Taxonomy and biology of proteocephalidean cestodes: Current state and perspectives. Helminthologia 2003, 40, 65-77.

91. Rego, A. Scolex morphology of proteocephalid cestodes parasites of Neotropical freshwater fishes. Mem. I. Oswaldo Cruz. 1999, 94, 37-52. [CrossRef]

92. Rego, A.A. Order Proteocephalidea Mola, 1928. In Keys to the Cestode Parasites of Vertebrates; Khalil, L.F., Jones, A., Bray, R.A., Eds.; CAB International: Wallingford, UK, 1994; pp. 257-293.

93. Adesina, O.O. Helminth Parasites of Anurans from a Riparian Habitat, Ikpako, Edo State. Postgraduate. Diploma Thesis, University of Benin, Benin, Nigeria, 2018.

94. Mettrick, D.F. A new cestode, Ophiotaenia ophiodex n. sp. from a night-adder, Causus rhombeatus (licht) in Southern Rhodesia. Proc. Helminthol. Soc. Wash. 1960, 27, 275-278.

95. Mettrick, D.F. Some cestodes of reptiles and amphibians from the Rhodesias. Proc. Zool. 1963, 141, 139-250. [CrossRef]

96. McAllister, C.T.; Freed, P.S.; Freed, D.A. Ophiotaenia ophiodex and Ophidascaris sp. in a spotted night adder (Causus maculata) from Cameroon, West Africa. J. Wildl. Dis. 1992, 28, 641-642. [CrossRef]

97. De Chambrier, A.; Ammann, M.; Scholz, T. First species of Ophiotaenia (Cestoda: Protocephalidea) from Madagascar; O. georgievi sp. n., a parasite of the endemic snake Leioheterodon geayi (Colubridae). Folia Parasit 2010, 57, 197-205. [CrossRef]

98. McAllister, C.T.; Bursey, C.R. A new species of Oochoristica (Cyclophyllidae: Linstowidae) from non-native Mediterranean geckos, Hemidactylus turcicus (Sauria:Gekkonidae) from Texas, USA. Acta Parasitol. 2017, 62, 296-305. [CrossRef]

99. Okafor, F.C. Oochoristica Baylis 1919 (Eucestoda: Linstowidae) in one reptile and two bat species from Nsukka (nambra State, Nigeria). Misc. Zool. 1988, 12, 11-15.

100. SouthwelL, T.; Lake, F. On a collection of cestodes from the Belgian Congo, with introduction by Jacques Schwetz. Ann. Trop. Med. Parasit 1936, 33, 63-90. [CrossRef]

101. Aisien, M.S.O.; Igetei, J.E. Oochoristica infection in anurans (Sclerophrys maculata and Ptychadena oxyrhynchus) from southern Nigeria. Herpetol. Notes 2018, 11, 901-905.

102. Jordano, D. Discovery of Diplopylidium triseriale in Spain (Cestoda: Dilepididae) and biometric demonstration of the validity of this species. Iberian J. Parasitol. 1951, 10, 97-124.

103. Casanova, J.-C.; Feliu, C.; Miquel, J.; Torres, J.; Spakulova, M. Faunistic and ecological trends on the helminthic community of Genetta genetta Linnaeus, 1758 (Carnivora: Viverridae) in the Iberian Peninsula. Helminthologia 2000, 37, $223-228$.

104. Torres, J.; Miquel, J.; Casanova, J.-C.; Ribas, A.; Feliu, C.; Morand, S. Endoparasite species richness of Iberian carnivores: Influences of host density and range distribution. Biodivers. Conserv. 2006, 15, 4619-4632. [CrossRef]

105. Millan, J.; Casanova, J. Helminth parasites of the endangered Iberian lynx (Lynx pardinus) and sympatric carnivores. J. Helminthol. 2007, 81, 377-380. [CrossRef] [PubMed]

106. Baer, J.G. Liste critique des parasites (monogènes, cestodes et trèmatodes) et de leurs hôtes en Républic de Côte d'Ivoire. Acta Trop. 1972, 29, 341-361. [PubMed]

107. Aisien, M.S.O. Parasites of the Herpetofauna of Nigeria, Volume One: Flatworms; Mindex Publishing Company Limited: Benin City, Nigeria, 2018. 